\title{
Any Prospect for Trade Union Revitalisation in Nigeria through Democratisation and Democratic Leadership?
}

\author{
Dr OYELERE Michael \\ European Business School London, Department of Management and Human Resources \\ Inner Circle, Regent's Park, London, United Kingdom \\ E-mail: OyelereM@REGENTS.AC.UK \\ Dr OWOYEMI Oluwakemi \\ Corresponding Author: oowoyemi@unilag.edu.ng \\ University of Lagos, Department of Industrial Relations and Personnel Management \\ E-mail: oowoyemi@unilag.edu.ng and oluwakemi.owoyemi@yahoo.com
}

\begin{abstract}
This paper takes a careful look at the socio-politico and economic developments within Nigeria. It is argued that a combination of these factors have severe consequences on the fortune and clout of the trade union movement. However based on the suppositions and prediction that civil government was likely, in retrospect, to bring about a turning point in the fortune of trade unionism, the paper examines the extent to which these assumptions are correct. The paper concludes that despite the high hopes and expectation generated by democratic governance elsewhere, the dividend in Nigeria, eleven years on, has been rather gloomy on the fortunes of the labour movement in the country. Hence, it is argued that these suppositions may be far fetched.
\end{abstract}

Keywords: Trade unions, clout, Political Changes, Nigeria

\section{Introduction}

The year 1999 was widely acclaimed as a year of economic recovery, social justice, freedom, and restoration of national pride in Nigeria, as the country moved towards democratisation after about two decades of continuous military rule that left the nation a pariah state (Ukiwu, 2003). During 1999, a fundamental change in the system of governance was completed, after several failed attempts. However, despite the high hopes and expectation generated by democratic governance elsewhere, the dividend in Nigeria, eleven years on, has been rather slow and negligible on the fortunes of the labour movement.

There has been decline, globally, in the fortunes of organised labour over the past two decades (Wood, 2002). This global decline has been attributed to several factors. Jones (1992) and Machin (2000) find that structural change, especially the move away from blue-collar jobs is a fundamental factor inducing membership decline. Low rates of recognition and resistance to unions in new establishments are also contributory (Machin, 2000, Chaison and Dhavale, 1990). In most developed countries the percentage of workers represented by trade unions fell precipitously (Blanchflower and Freeman, 1992). Wood and Harcourt (1998) posit that, in the United States, unions witnessed a decrease from 22 percent to 16 percent between 1980 and 1990. Conversely, a similar proportion of decline was noted in the United Kingdom and other advanced countries within the Organisation of Economic Co-operation and Development (OECD).

In developing economies, except in South Africa, where Wood (2002) noted that involvement of labour movement in the struggle against apartheid government has aided its new organising strategy, most other countries have been through a period of decline. Kuruvilla, Das, Kwon and Kwon, (2002) concludes that though there were variations in union density, most of the countries examined experience decline. In Nigeria however, the level of membership remained relatively stable during the 1980s and 1990s despite the fact that the country was under a dictatorship (Tokunboh, 1985). Many other causes of decline, including the closure of textile industries, rendered one of the strongholds of unions helpless. Then the introduction of Structural Adjustment Programme (SAP) policies, which led to mass retrenchment in the public sector, may have had some negative impact on the level of membership in Nigeria. However, they were overshadowed by the single understanding amongst union members of the need to be united against the authoritarian regime of military administrators.

\section{Nigeria's political structure and leadership}

The Nigeria's political landscape has been characterised by a series of military interventions since 1966 . Nigeria gained independence from her colonial leaders on $1^{\text {st }}$ October 1960 and became a republic in 1963. However, by 
January 15,1966 , the country witnessed her first military coup. The coup temporarily distorted the Hausa/Fulani hegemony and political machinery and introduced Major General Johnson Aguiyi-Ironsi, (an Igbo), as the first military head of state (Miners, 1971). Although Ironsi was not part of the coup plot, he took over power as the commander of the armed forces since the conspirators failed to take control of government due to their naivety and their lack of experience. The northern elements were greatly displeased by the coup. This was not only because they lost control of power and their prominent politician and military officers, but also because Ironsi failed to order the trial of the coup plotters and the promulgation of Decree No. 34 of 1966. The decree abrogated the federal system of government and introduced a unitary system.

The disaffection among northern elements within the military was considered to be responsible for the immediate overthrow of the Ironsi led junta (Luckham, 1971). The northern soldiers received moral support from their emirs and leaders of thought. They staged a counter-coup in July of the same year. The coup led to the assassination of the head of state - Ironsi, who was immediately replaced with Lieutenant Colonel Yakubu Gowon (a Northerner). Despite all the effort of Gowon's government, relations between the federal government and the eastern region leaders remained strained and the governor of the region, Colonel Chukwuemeka Odumegwu Ojukwu, maintained that the killing of easterners in the north and the elimination of officers of Igbo origin during the coup was not acceptable (Anber, 1967).

Consequently, Ojukwu, on May 30, 1967 made a proclamation of an independent Republic of Biafra (Luckman, 1971). This led to the declaration of war on the fledging Republic of Biafra. The war lasted thirty months and ended in January 1970. The Gowon government accepted Biafra's unconditional cease-fire (St. Jorre, 1972), and declared that there would be no victor and no vanquished. In this spirit, the years afterward were declared a period of rehabilitation, reconstruction, and reconciliation. In addition to the reconciliation, rehabilitation and reconstruction exercises, the post-war Gowon government also arranged a transition programme aimed at handing over power to a civilian government on October 1, 1976 (Osaghae, 1998).

Unfortunately by July 29, 1976, Gowon's junta was overthrown in what (Ademoyega, 1981, Garba, 1982) described as a palace coup. General Murtala Muhammad, also a northerner but a muslim by religion, took over from Gowon. Muhammad ruled for only seven months within which he endeared himself to most Nigerians because of his strong leadership qualities and the radical reforms he introduced in domestic and foreign policies (Ejoor, 1989). He introduced measures to eliminate indiscipline in state owned agencies. In order to gain popular acceptance among minority groups in the country, Murtala set up a panel headed by Justice Ayo Irikefe to advise on the creation of more states. The Irikefe report led to the creation of seven additional states (Akinyele, 1996) in 1976. Additionally, the regime set up a panel under Justice Akintola Aguda to consider the need for a creation of a new federal capital (Moore, 1984), because of the congestion in Lagos.

The assassination of Murtala on February 13, 1976 in an unsuccessful coup attempt led by an officer from the middle belt, Colonel Bukar Dimka, (Ihonvbere, 1991) noted, was designed to re-install Gowon, who was at that time in exile. The failure of the coup paved way for Obasanjo, a Yoruba and southerner, and second in command to Murtala to take over as head of government.

Initially, the Obasanjo regime lacked support and popularity especially among the northerners, who saw Murtala as a hero. The regime however succeeded in many areas of his administration. Obasanjo became an adept political ruler, determined not to exacerbate any difference between the geo-political groups, especially the north-south and muslim-christian schisms among the regions.

A significant aspect of the regime, which is relevant to the subject of the current paper, was the promulgation of the Trade Unions (Central Labour Organisations) (Special Provisions) Decree 1976 (No. 44). The decree assisted the newly created Nigeria Labour Congress (NLC) to consolidate its grip over trade union members of dissolved labour centres. However, the decree did not create the NLC. Apart from successfully completing the complex process of transition to civilian rule, the regime was also known for many reforms introduced in the three years period of the government. Many of these reforms directly impinged on the right and ability of labour movement to organise and recruit workers. Trade Disputes (Essential Services) Act 1976 (No. 23) allows the President to proscribe any trade union or association representing employees. The Trade Disputes Act 1976 (No. 7) established the National Industrial Court with jurisdiction over trade dispute matters. Trade Unions (Prohibition) (Federal Fire Service) Order 1976 (N.42) prohibits members of the Federal Fire Service from organising or becoming members of a trade union.

\section{Second republic, 1979-83}

The Obasanjo transition to civil rule began with the lifting of ban on political activities in September 1978. The ban came into force in 1966, when the first military coup took place. He also established the Federal Electoral 
Commission (FEDECO) to register political parties and monitor the conduct of elections. The government did emphasise the need for political parties to be national in outlook, rather than what was the case during the first republic - regional parties (Falola and Ihonvbere, 1985). Regional political activities, they claimed, engendered the collapse of the first republic. After the lifting of the ban, at least fifty-three political associations were formed (Oyediran and Agbaje, 1991), out of which only seventeen applied for registration. After due consideration, FEDECO registered the following five parties: National Party of Nigeria (NPN), Nigerian People's Party (NPP), Unity Party of Nigeria (UPN), Great Nigeria People's Party (GNPP), and People's Redemption Party (PRP). In 1981, a sixth party, Nigeria Advance Party (NAP), was registered.

The Shagari-led NPN, like its predecessor the Northern Peoples Congress (NPC) was declared the winner of the 1979 election. On assumption of office in 1979, Alhaji Aliyu Shehu Shagari became the first executive president of Nigeria. His government however was plagued by several factors similar to those of the first republic. A number of weaknesses beset the second republic (Falola and Ihonvbere, 1985). First, the oil boom ended in mid-1981. Second, there was lack of co-operation between the NPN-dominated federal government and the twelve states controlled by opposition parties. Third, the coalition that dominated federal politics was not strong, and in effect, the NPN governed as a minority because no coalition was formed to challenge its supremacy. In addition, many other factors led to tension in the country, which eroded the ability of the ruling party to govern (Diamond, 1988, Koehn, 1989, Shettima, 1995).

Apart from the fall in the prices of crude oil, recession also crippled the economy. However, for political reasons the government continued to accelerate its spending on projects whose usefulness or value to development were questionable at the time (Shettima, 1995). The collapse of world oil market prices hampered the ability of the government to meet up with the payment of workers' wages. Consequently, industrial unrest began, with the demand for payment of salary arrears and fringe benefits. The government found itself losing control of organised labour, as the numbers of strikes left the administration in disarray. The two-day national strike organised by the NLC in May 1981, attracted support from over 700,000 of the one million unionised workers (Othman, 1984).

The increase in foreign debt from N3.3 billion in 1978 to N14.7 billion in 1982 (Adesina, 1994) displayed the insensitivity of the government to economic realities. However the administration attempted to accept the IMF loan and to implement its conditionality - removal of petroleum subsidy. The NLC objected to this, because it believed this would induce inflation and contribute to an already deplorable condition of workers by reducing their purchasing power (Lewis, 1994).

\section{The Return to Military Rule}

\section{December $31^{\text {st }} 1983$ coup and government}

The overthrow of Shagari's government meant the end of the second republic. Major General Muhammadu Buhari, a Hausa/Fulani northerner from Katsina State, whose background and political loyalties tied him closely to the Muslim north and the deposed government, became the head of state. Buhari was not naïve in the administrative system of the country. He had been part of administration with previous military juntas. Under the Muhammad/Obasanjo government, he served as a member of the Supreme Military Council (SMC).

Buhari's administration tried to restore public accountability and to re-establish a dynamic economy without altering the basic power structure of the country. Politically, the regime retained a structure similar to those of Murtala/Obasanjo juntas. Nevertheless, Buhari's economic aims were almost identical to those of the ousted civilian regime led by Shagari. The regime subtly began the implementation of SAP conditionalities demanded by the IMF and the WB. It paid off most salary arrears of civil servants, but consequently laid off a huge number of workers in the public sector. The regime also introduced the War Against Indiscipline (WAI) to express their will and determination to stamp out all forms of the indiscipline in the Nigerian society. Although this regime managed to push the debt-service ratio to around 40 per cent (Olukoshi, 1990), its authoritarian nature and ambiguous relationship with the IMF led it into open clashes with the Nigerian populace especially the trade union movement, the press, student organisations and the academic community (Adesina, 1994). Moreover, mass retrenchment of civil servants across the country led to an outcry by most Nigerians.

The major problem that confronted the regime was Nigeria's foreign debt. Negotiations with the IMF dragged on, and in the end efforts to reschedule the debt failed (Olukoshi, 1990). Although Buhari was dedicated to austerity measure plans, the IMF insisted on even more drastic measures of cutting spending, devaluating the currency, and otherwise restructuring the economy, than most Nigerians were willing to accept. Buhari acceded to harsh IMF terms against the strong wishes of most Nigerians (Lewis, 1996). Nigerian nationalism won out over economic necessity, especially the incessant retrenchment of worker in government establishments. 
Consequently organised labour began to demand that the government stop the retrenchment of workers and the implementation of the SAP policies. In order to silence labour and other critics, Decree No. 2, (Detention of Persons) which gave the government the right to detain indefinitely, without trial, any person(s) it suspected to be a "threat to the nation" and the Public Officers (Protection Against False Accusation) Decree No. 4, which essentially criminalised any unfounded allegation against government officials in the press, were promulgated.

The introduction of these decrees rendered organised labour ineffective. Moreover, threat and force was used by government agencies to cull all opposition. Many labour leaders were arrested and detained without trial. As a result, industrial unrest was brought to the lowest level. Working days lost through strikes for instance, declined from 9.6 million in 1982 to 200,000 in 1985 (Mosley, 1992). This attack on labour only bottled the grievances against government and its policies. Trade unions became stronger and were resolute in their struggle; also membership grew, albeit without corresponding growth in influence.

\section{August $27^{\text {th }} 1985$ coup and Babangida government}

Economic crisis, labour outcry and civilian criticism of the military, undermined Buhari's position, and in August 1985, a group of officers under Major General Ibrahim Babangida removed Buhari from power. Babangida was a more systematic ruler, with quite a different style when compared with his predecessor. Babangida was reported to have taken part in all the military coup attempts in Nigeria. That, according to (Lewis, 1999), explains his confident handling of national affairs. Babangida claimed that the Buhari regime was too dictatorial, and he came to ameliorate the sufferings of Nigerians. Although at the inception of his regime, Babangida was regarded as a hero and champion of human rights, this record however deteriorated over time. The regime failed to hand over to the civilian after a long and inconclusive transition programme that left the country to service a debt of billions of naira (Lewis, 1999). The administration was very repressive and nonchalant, and never in the history of the country have the coercive powers of the State, particularly the security and intelligence agencies, been deployed with such single-mindedness to the detriment of individuals and institutions (Otobo, 2004).

Babangida, despite the resounding rejection of the IMF/WB proposed conditionalities by Nigerians (Adesina, 1994) in June 1986, began the implementation of SAP. Trade unions under this situation, like the preceding one, found it difficult, if not impossible, to devise any strategy to cope with the mounting mass layoff of workers, redundancies and increasing level of unemployment. Although the regime abolished Decrees No. 2 and 4, it however enacted more subtle decrees aimed at subverting the unions. Trade Unions Miscellaneous Provisions Decree No. 17 of 1986, amended the Trade Unions Act 1973, by detailing the list of registered and recognised trade unions, and specifying unions that may be affiliated to the Central Labour Organisation. Trade Unions (International Affiliation) Act 1973 (No. 35 of 1989) determined international unions with which the NLC could affiliate, and provided for penalties for its contravention. Trade Disputes (Amendment) Decree 1992 (No. 47), also amended the Trade Disputes Act by excluding the jurisdiction of court on matters relating to trade disputes, leaving such matters to the mercies of the executive.

Although Babangida began a transition programme in 1985, it remained inconclusive by 1993, due to the annulement of the June 12, 1993 presidential election won by Chief M.K.O. Abiola (Ojo, 2000). His transition was expensive, byzantine, prolonged, and dubious (Ihonvbere, 1991). The annuled election was however unique to most Nigerians for two reasons: 1). It was a transition from military to civilian rule; and, 2). It presented the opportunity, for the first time, to the Southern elite, to take control of civil leadership. This hope was however short lived. On 23rd June 1993, Babangida announced the suspension of the National Electoral Commission (NEC) and annulled the election results. The annulment of the election result could hardly be comprehended by the Yorubas, as this was their first clear chance to break the northern hegemony. The annulement thus led to unrest in many parts of the country (Sesay and Ukeje, 1999). The disagreement and unrest paved the way for the military to hang on to power. However, Babangida could not continue in office and decided to "step aside" (Ojo, 1997).

Shonekan's interim government, Abacha coup of November $17^{\text {th }} 1993$, Abdulsalam's regime and the Obasanjo civil administration

Due to resentment and the chaotic political state following the annulment of June 12 presidential election, the Babangida regime was unable to continue in power. Consequently, Chief Ernest Shonekan's interim government was constituted to replace the junta. Shonekan's rule was designed by Babangida to appease the Yorubas, who saw the annulment of the June 12 election as a plot to prevent them from ruling, and to entrench the Hausa/Fulani hegemony. The interim regime, however, barely lasted for two months, before being overthrown by General Sani Abacha, the Vice-President to Shonekan, on November 17, 1993.

Upon assumption of office, General Abacha dissolved the entire political structure that Babangida's transition put in place. Military officers replaced local and state executives. Supreme executive and legislative powers were vested in 
the Provisional Ruling Council (PRC). General Abacha became both the Commander-in-Chief of the Armed Forces and the Head of State. Due to pressure from internal and external sources, especially the sanction from the Commonwealth, the Abacha junta announced a three-year programme for transition to civilian rule in 1995 (Sesay and Ukeje, 1999). The transition programme was similar to that of his predecessor. Momoh and Adejumobi (1999) summits that the Abacha transition programme, like the Babangida episode, was a political fraud designed to entrench the junta in power. However, his sudden and unexpected death on June 8, 1998 paved way for General Abubakar Abdulsalam to steer the course of a new transition.

Organised labour was perpetually kept under check throughout the life of Abacha's regime. He introduced several decrees to undermine union campaigns. First, the national executive of NLC was dissolved through Decree No. 9 of 1994 (Dissolution of National Executive Council- NEC). The decree dissolved the NEC of the NLC, the Central Working Committee of the NLC and "any other national body or committee by whatever name called in the Congress". Second, Decree No. 10 of 1994 was enacted. The decree dissolved the National and State Executive Councils of the National Union of Petroleum and Natural Gas Workers (NUPENG) and Petroleum and Natural Gas Senior Staff Association of Nigeria (PENGASSAN), and "any other national or state body by whatever name called in NUPENG or PENGASSAN" (Akinlaja, 1999). Third, Trade Disputes (Essential Services) (Proscription) Order 1996 Proscribing several trade unions and associations of staff of universities, and research institutes. Fourth was the Trade Unions (Amendment) Decree No. 26 of 1996 which permits the Minister of Labour to revoke certification of a trade union due to "overriding public interest", and prohibits persons who are not members of any trade union or who do not practice a profession which a trade union represents from participating in a union or the Central Labour Organisation.

Particularly, this decree was aimed at preventing other civil organisations and social union movements and the unorganised informal sector from supporting the political cause of organised labour. In addition, the decree contained a schedule list of trade unions, which should be given recognition by employers and their respective jurisdictions. Finally, like the earlier military regimes, Abacha, introduced a decree to prevent unions from affiliating with international bodies hoping this will prevent external support for the unions.

Although the role of labour was undermined by authoritarian rule, we cannot afford to ignore their social and political contributions in ousting the military. Despite the decrees and other authoritarian tactics employ by the Abacha regime, we find labour organising and staging national strikes and protests with significant outcome and implications. First, in July 1994, the NLC, NUPENG and PENGASSAN, National Union of Nigerian Students and pro-democracy organisation masterminded a national strike to protest the annulment of the June 12 presidential election (Ihonvbere, 1997). Secondly, was the national strike ignited by Academic Staff Union of Universities (ASUU) over demand for increased funding for universities, reinstatement of over eighty lecturers whose appointment were terminated at the University of Abuja and the de-annulment of June 12, 1993 presidential election. Thirdly, a national protest against Decree No 12 of 1994, introduced to block any legal challenge by the NLC and oil union executives against their dismissal by the government. Finally, a nation-wide protest held in disapproval to a decree empowering the junta to arbitrarily detain without charge or trial any person considered a threat to national security.

This political role embarked upon by the trade union had in no small measure, contributed to making governance difficult for the junta. Indeed the inhuman treatment of labour activists and especially the killing of Ken Saro-Wiwa, earned the nation sanction from the Commonwealth.

It is evident from the type of transition Abacha introduced that he was not willing to relinquish power, his sudden death however paved way for a new transition programme.

Upon his death, General Abdulsalam took control of government, and announced his intention to hand over power to the civilian populace within the shortest possible period. He commenced his new transitional course by releasing political prisoners and appealed for support from the international community. In response to his appeal, the United Nations Secretary-General Kofi Annan visited Nigeria, promising support to the government, and sought Chief Abiola's release from prison.

Amongst the goals of the regime, was the desire to launch Nigeria back into the community of nations, rejuvenate the country's economy, and return the country to civil rule. Consequently, the regime resumed a programme of reconciliation and consultations Sasey and Ukeje (1999), with all stakeholders within and outside the country. The five political parties registered under the Abacha administration were dissolved and their assets handed over to administrators (Reno, 1999). Correspondingly, all previous elections conducted under these parties were cancelled. As a result, senior civil servants were posted to take charge of local government councils, for the management of their affairs (Momoh and Thovoethin, 2001). 
In order to have a credible transition, the existing electoral commission, the National Electoral Commission (NECON), was disbanded and a new electoral body - the Independent National Electoral Commission (INEC) was set up (Momoh and Thovoethin, 2001). As in the previous cases, INEC was granted power to register voters and parties, also to conduct fresh elections at all levels of government. Although nine political parties were registered and allowed to field candidates in the December 5, 1998 Local Government council elections Momoh and Thovoethin (2001), only three - Alliance for Democracy (AD), All Peoples Party (APP), and Peoples Democratic Party (PDP) - made the final registration (Enemuo, 1999).

Initial election results revealed that PDP, with strong base among the Hausa/Fulani of the north, won majority seats. However it was due to general consensus among the political class, that the Yorubas be compensated, for the purported injustice caused by the annulment of the June 12 presidential election and in the interest of peace and national unity, Obasanjo was elected the presidential candidate of PDP. In a similar development, the AD and the APP alliance presented Chief Olu Falae (Ibrahim, 1999; Lewis, 2003). When the election was eventually held, the PDP candidate won majority vote and was declared winner irrespective of the reported low turnout of voters and the irregularities observed by international election monitoring groups.

Under the Abdulsalam regime, organised labour was able to negotiate for a national minimum wage. For the first time, minimum wage was introduced, based on the recommendation of a tripartite committee (including representatives of the ILO). Due to the transparency of the transition process, organised labour supported the government and called on its members to exercise their franchise in order to ensure the success of the programme. Unlike in 1992, when labour attempted to register and field candidates for the elections, labour unions gave their support to candidates from parties they believed would best serve the interest of labour.

\section{Nigeria's Labour Movement: State and Predicaments}

Industrial relations during the immediate post-military era can be said to have been characterised by series of crises, which in the main, have inundated the body polity, dramatically revealing the fragility of the State and the contradictions inherent in the political democratisation that left foreign economic domination yet unaltered. A highlight of the political activities that led to the current situation has been discussed above. However, it important to stress that political transition in Nigeria has been based not only on the military ruler's conviction that civil rule was desirable, but also on the expectation of the people that, after the military performed its rescue operation it should relinquish power to the civilians, and the clamour for democratic rule around the globe.

Today, the labour movement in Nigeria could certainly be said to be more organised than what obtained in the 1960s and 1970s (Adewumi, 2007). The central trade union in the country is the NLC, which was formed in 1975 as the umbrella trade union and recognised by Decree Number 44 of 1976 as the sole representative of unions in the country. It has representative bodies all over the country, with a national executive body and a secretariat, as well as state councils in all States of the Federation. It has 29 affiliate unions with membership of well over four million spanning the public and private sectors (NLC, 2004).

The organisation has had a chequered history, surviving two instances of dissolution of its national organs under military juntas and a third from a civilian administration. Arbitration, prolonged and unlawful detention of labour leaders, invasion and disruption of union meetings, seminars and other activities of congress and its component by security forces and a vicious anti-labour campaign by the State generally marked the military era of Nigeria's polity, while both the civil and military regimes invoked legislative prerogatives to unleash all manner of legislation to check the activities of unions.

Attempts by the Obasanjo administration to proscribe the NLC in 2004 failed in the face of rising internal and external opposition. The administration however, continued in its bid to frustrate the activities of the movement and treat the NLC with hostility. Despite intensified use of machinery of oppression and legislative weaponry by current civilian government, the political role of labour has remained imperative not only to union members but also to most Nigerians. Unions have organised and participated in protests and strikes of varying magnitude, to force the government to revert some of its economic decisions. In June 2000, a national strike was held to protest the 50 per cent increase in the prices of petroleum products. The success of the strike forced the government to withdraw the earlier increase made on these products.

Consequently, the government set up a committee to negotiate with labour. However, by February 2001, Obasanjo overlooked the agreement, arguing that it was becoming increasingly difficult to sustain the agreed prices on petroleum products. As a result, prices were again increased. Labour as well proceeded on a strike after the expiration of a seven-day ultimatum given to the government. On this occasion, the government went to court challenging the action of the NLC. The court declared NLC actions as illegal. In deference to the court decision, the NLC Central Working Committee called off the strike. During the life span of the Obasanjo regime the prices of 
petroleum products was increased a record six times in a single administration and on each of these occasions, labour has resisted and fought to revert or at least obtain a reasonable pricing. Apart from this, labour has on many occasions protested on the issues of minimum wage, privatisation of state owned enterprises, and retrenchment of workers.

The NLC has made significant impact on the nature, structure and implementation of government programmes. Although the political role of unions continues to increase in sphere, their impact diminished under the Obasanjo administration. Events evolving since 2004 in industrial relations reveal that the State in democratic dispensation is still coercive. In June 2004, the government announced its plan to decentralise the labour union and remove the oil subsidy. Consequently a bill to amend the Trade Union Act was sent to the National Assembly. The bill sought to proscribe the NLC and fragment the trade unions; make strike action impossible, make recognition difficult; and, freeze union sources of finance.

Consequent to the immediate action taken by the NLC with support from the ILO, the National House of Assembly reworded the bill, and passed a law which was slightly different from what the executive have proposed. However, the executives' action, despite earlier setting up a stakeholders committee, including the ILO, to review the industrial and labour relations laws in the country, revealed the government's repressive and draconian stand in industrial and labour relations. Arguably this may not affect the struggle by labour due mainly to the prevailing problem in the economy. The fact however is that while these problems lead to increasing demand for labour's political role, their clout will continue to diminish.

\section{Concluding Remarks}

Most previous studies in this area in Nigeria has focused on the actions of the unions, especially organising unionism. They ignored the impact of external environment on trade unions, and has been descriptive and narrowly focussed. This study however draws on political activities and industrial relations. The paper sought to better understand the effect of external environment, especially the political environment, on trade unionism. The paper did not found enough support for the hypothesised model of democratic government support for trade unionism. The study revealed that although political system has changed from military to civilian, the actors mostly remain the same and continue to perpetuate autocratic tendencies within a civil dispensation.

The study has presented a chronicle of the Nigeria's political system since independence and discussed the impact of successive government regulations on the labour movement. In addition to the political antecedents, the study demonstrated how successive government, mostly military, attempted to usurped the labour movement. The paper concludes that trade unions sometimes shares political unionism's goals, which are intended to transform society according to working-class interests but remains independent from government and other civil liberty groups.

An apt summary would be that while the influence of labour movement have been badly affected by military rule, recent democratic rule have given something different, even though, this does not match the expectation of the unions, academics and human right commentators. Legal changes have altered union's right and power. Economic changes would not permit the exercise of bargaining power. However, it is important that we do not write off Nigeria's labour movement, the formation and registration of labour party with influential candidates in many states is a sign that labour could turn the environment around through political activism.

\section{References}

Ademoyega, A. (1981). Why we struck: the story of the first Nigerian coup. Ibadan: Evans Brothers.

Adewumi, F. (2007). Unity and Division: the Dialectics of the Nigerian Trade Union Movement. African Journal of Business Management 1 (3) 55 - 63

Adesina, J. O. (1994). Labour in the Explanation of an African Crisis: A Critique of Current Orthodoxy: The Case of Nigeria. CODESRIA.

Akinlaja, J. I. (1999). NUPENG: An Example in Progressive Unionism. Lagos: Inspired Communication Ltd.

Akinyele, R. T. (1996). States Creation in Nigeria: The Willink Report in Retrospect. African Studies Review, 39, (2), 71-94.

Anber, P. (1967). Modernisation and Political Disintegration: Nigeria and the Ibos. The Journal of Modern African Studies, 5 (2), 163-179.

Blanchflower, D. G. and Freeman, R. B. (1992). Unionism in the United States and other advanced OECD countries. Industrial Relations, 31 (1), 56-80. 
Chaison, G. N. and Dhavale, D. G. (1990). A Note on the Severity of the Decline in Union Organizing Activity. Industrial \& Labor Relations Review, 43 (4), 366 - 372.

Charlwood, A. (2004). Influences on Trade Union Organizing Effectiveness in Britain. British Journal of Industrial Relations, 42 (1), 69-93.

Diamond, L. J. (1988). Class, ethnicity, and democracy in Nigeria : the failure of the First Republic. Syracuse, N.Y: Syracuse University Press.

Ejoor, D. A. (1989). Reminiscences. Lagos: Malthhouse press.

Enemuo, F. C. (1999). Elite Solidarity, Communial Support, and the 1999 Presidential Election in Nigeria. Journal of Opinion, 27 (1), 3-7.

Falola, T. and Ihonvbere., J. (1985). The rise \& fall of Nigeria's second republic, 1979-84. London: Zed.

Garba, J. (1982). Revolution in Nigeria: Another view. London: African books Ltd.

Ibrahim, J. (1999). Political Transition, Ethnogregionalism, and the "Power Shift" Debate in Nigera. Journal of Opinion, 27 (1), 12-16.

Ihonvbere, J. O. (1991). A Critical Evaluation of the Failed 1990 Coup in Nigeria. The Journal of Modern African Studies, 29, (4), $601-626$.

Ihonvbere, J. O. (1997). Organised Labor and the Struggle for Democracy in Nigeria. African Studies Review, 40 (3), 77-110.

Jones, E. B. (1992). Private Sector Union Decline and Structural Employment Change, 1970-1988. Journal of Labor Research, 13 (3), 257-272.

Koehn, P. (1989). Competitive Transition to Civilian Rule: Nigeria's First and Second Experiments. Journal of Modern African Studies, 27 (3), 401-430.

Kuruvilla, S., Das, S., Kwon, H. and Kwon, S. (2002). Trade Union Growth and Decline in Asia. British Journal of Industrial Relations, 40 (3), 431-461.

Lewis, P. M. (1994). Endgame in Nigeria? The Politics of a Failed Democratic Transition in Nigeria. African Affairs, 94 (372), 323-340.

Lewis, P. (1996). From Prebendalism to Predation: The Political Economy of Decline in Nigeria. Journal of Modern African Studies, 34 (1), 79-103.

Lewis, P. M. (1999). "Nigeria: An End to the Permanent Transition?" Journal of Democracy, 10 (1), 141-156.

Lewis, P. M. (2003). "Nigeria Elections in a Fragile Regime" Journal of Democracy, 14 (3), 131-144.

Luckham, A. R. (1971a). Institutional Transfer and Breakdown in A New Nation: The Nigerian Military. Administrative Science Quarterly, 16 (4), 387-406.

Luckham, R. (1971b). The Nigerian military: A sociological analysis of authority and revolt 1960-67. London: Cambridge University Press.

Machin, S. (2000). Union Decline in Britain. British Journal of Industrial Relations, 38 (4), 631-645.

Miners, N. J. (1971). The Nigerian Army 1956 - 1966. London: Methuen \& Co Ltd.

Momoh, A. and Adejumobi, S. (1999). The Nigerian military and the crisis of democratic transition: a study in the monopoly of power. Lagos: Civil Liberties Organisation.

Momoh, A. and Thovoethin, P.S. (2001). An Overview of the 1998-1999 Democratisation Process in Nigeria. Development Policy Management Netwok Bulletin, 13 (3), 4-9.

Moore, J. (1984). The Political History of Nigeria's New Capital. The Journal of Modern African Studies, 22 (1), $167-175$.

Mosley, P. (1992). Policy-Making without Facts: A Note on the Assessment of Structural Adjustment Policies in Nigeria, 1985-1990. African Affairs, 91 (363), 227 -240.

NLC (2004). Anti-LabourBill: Obasanjo vs The People. Labour News, Special Edition, (116-6991), p.16-17.

Ojo, E. O. (1997). The Form and Character of Nigerian Civil Society vis-a-vis Democratic Stability: A Case Study of the June 12, 1993 Presidential Election Impasse in Nigeria. Nigerian Journal of Political Behavior, 1 (1), 7 - 14. 
Ojo, E. O. (2000). Military and democratic transition in Nigeria: An in depth analysis of General Babangida's transition programme (1985-1993). Journal of Political and Military Sociology, Summer 1-15.

Olukoshi, O. (1990). Nigerian External Debt Crisis: its Management. Lagos: Multhouse.

Osaghae, E. E. (1998). Managing multiple minority problems in a divided society: the Nigerian experience The Journal of Modern African Studies, 36 (1), 24.

Othman, S. (1984). Classes, Crises and Coup: The Demise of Shagari's Regime. African Affairs, 83 (333), 441-461.

Otobo, D. (2004). Association of African Universities Staff Exchange Programme 2003-2004 (Ed, Otobo) University of Witwaterstrand, South Africa, pp. 22.

Oyediran, O. and Agbaje, A. (1991). Two-Partyism and Democratic Transition in Nigeria. The Journal of Modern African Studies, 29 (2), 213-235.

Phillips, C. S. (1980). Nigeria's New Political Institutions. The Journal of Modern African Studies, 18 (1), 1-22.

Reno, W. (1999). Crisis and (No) Reform in Nigeria's Politics. African Studies Review, 42 (1), 105-124.

Sesay, A. and Ukeje, C. (1999). The West and Elections in Nigeria. Journal of Opinion, 27 (1), 34 - 37.

Shettima, K. A. (1995). Engendering Nigeria's Third Republic. African Studies Review, 38 (3), 61-98.

St. Jorre, J. D. (1972). The Nigerian Civil war. London: Holder and Stoughton.

Tokunboh, M. A. (1985). Labour Movement in Nigeria: Past and Present. Lagos: Literamed.

Ukiwo, U. (2003). Politics, Ethno-Religious Conflicts and Democratic Consolidation in Nigeria. Journal of Modern African Studies, 41 (1), 115-138.

Wood, G. (2002). Organising Unionism and the Possibilities for Perpetuating a social Movement Role: Representivity, Politics, and the Congress of South African Trade Unions. Labour Studies Journal, 26 (4), 29-50.

Wood, G. and Harcourt, M. (1998). The Rise of South African Trade Unions. Labor Studies Journal, 23 (1), 74 - 92. 